\title{
IN THE CROSSFIRE
}




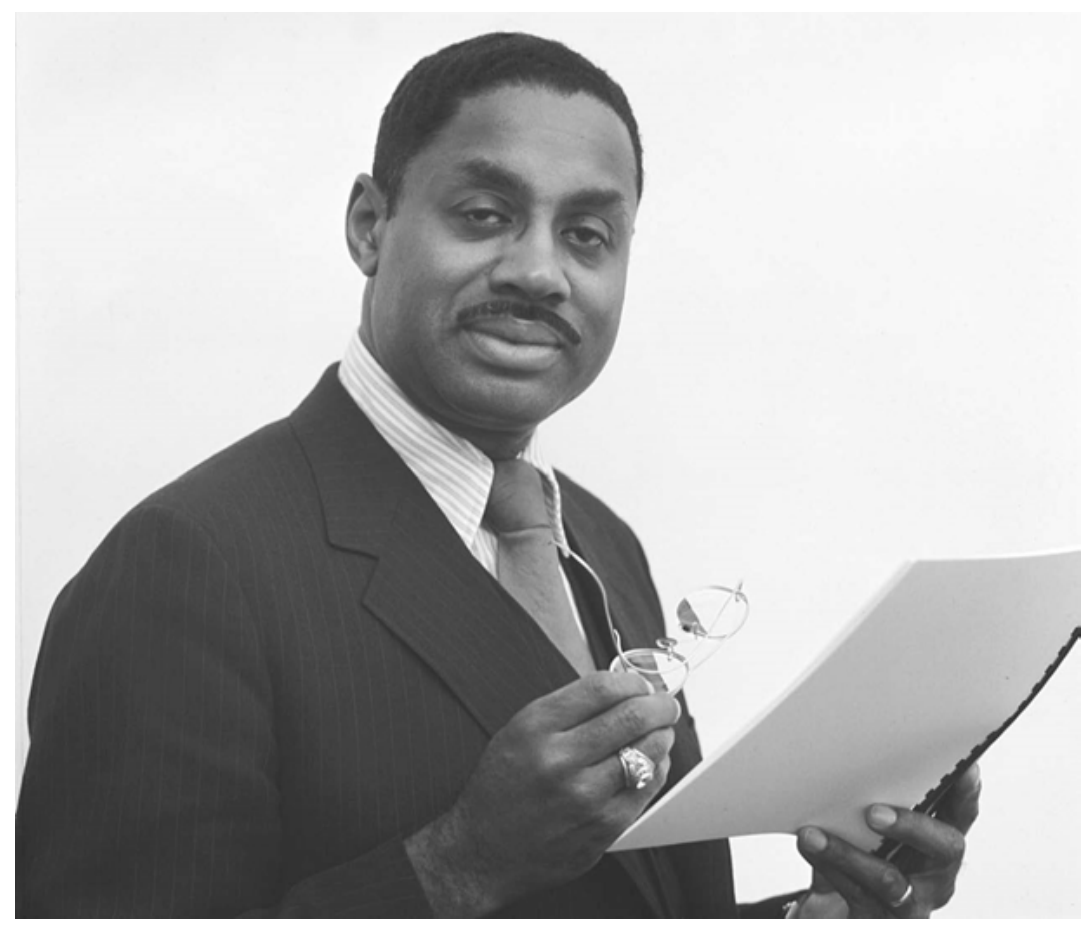




\section{IN THE CROSSFIRE}

Marcus Foster and the Troubled History of American School Reform

\section{JOHN P. SPENCER}

\section{$\overline{\text { PENN }}$}




\title{
POLITICS AND CULTURE IN MODERN AMERICA
}

\author{
Series Editors: Margot Canaday, Glenda Gilmore, \\ Michael Kazin, and Thomas J. Sugrue
}

Volumes in the series narrate and analyze political and social change in the broadest dimensions from 1865 to the present, including ideas about the ways people have sought and wielded power in the public sphere and the language and institutions of politics at all levels-local, national, and transnational. The series is motivated by a desire to reverse the fragmentation of modern U.S. history and to encourage synthetic perspectives on social movements and the state, on gender, race, and labor, and on intellectual history and popular culture.

Copyright $@ 2012$ University of Pennsylvania Press

All rights reserved. Except for brief quotations used for purposes of review or scholarly citation, none of this book may be reproduced in any form by any means without written permission from the publisher.

\author{
Published by \\ University of Pennsylvania Press \\ Philadelphia, Pennsylvania 19104-4112 \\ www.upenn.edu/pennpress
}

Printed in the United States of America on acid-free paper

10987654321

Library of Congress Cataloging-in-Publication Data

Spencer, John P.

In the crossfire : Marcus Foster and the troubled history of American school reform/John P. Spencer. - 1st ed.

p. cm. - (Politics and culture in modern America)

Includes bibliographical references and index.

ISBN 978-0-8122-4435-9 (hardcover : alk. paper)

1. Foster, Marcus A., 1923-1973. 2. African Americans_Education. 3.

Educational change-United States. 4. African American school principalsPennsylvania—Philadelphia. 5. African American school superintendentsCalifornia—0akland. 6. Urban schools—Pennsylvania—Philadelphia. 7.

Urban schools-California-0akland. I. Title. II. Series: Politics and culture in modern America.

LA2317.F677S64 2012

$370.92-\mathrm{dc} 23$

[B]

2012002587

Frontispiece: Marcus A. Foster, 1969.

Urban Archives, Temple University Libraries. 
For Eve, and Ella and Owen 
This page intentionally left blank 